\title{
INCISION BELOWTHE CLAMP SEBAGAI MODIFIKASI TEKNIK INSISI PADA FRENEKTOMI UNTUK MINIMALISASI PERDARAHAN
}

\author{
Suryono \\ Bagian Periodonsia, Fakultas Kedokteran Gigi, Universitas Gadjah Mada Yogyakarta
}

\begin{abstract}
ABSTRAK
Latar Belakang. Perlekatan frenulum tinggi berdampak merugikan bagi jaringan periodontal maupun fungsi estetik. Perlekatan tinggi yang terjadi pada labialis superior, menimbulkan gingivitis dan sentral diastema yang menjadikan indikasi untuk dilakukan frenektomi. Frenektomi dengan teknik melakukan insisi di atas dan di bawah clamp berakibat lebarnya luka karena tarikan otot bibir, yang berdampak terjadi banyak perdarahan. Tujuan. Melakukan evaluasi terhadap modifikasi teknik insisi yang diharapkan dapat mengurangi perdarahan. Kasus dan Penanganan. Laporan kasus ini memaparkan penanganan kasus pada perlekatan frenulum tinggi yang diikuti adanya sentral diastema. Pasien dengan diagnose frenulum tinggi dan indikasi frenektomi dilakukan tindakan preoperasi, Tindakan operasi dilakukan dengan menggunakan pisau bedah, modifikasi insisi (Insision below the Clamp) dilakukan dengan cara menempatkan clamp frenulum pada posisi yang berdekatan dan sejajar dengan bibir, tindakan insisi dilakukan di bawah clamp, disusul dengan penjahitan pada area mucolabial fold. Selama operasi dilakukan terlihat luka tidak melebar, tidak banyak darah yang keluar, pasien dan dokter merasa nyaman. Kesimpulan. Insision below the Clamp merupakan modifikasi teknik insisi pada frenektomi yang bisa dilakukan oleh para praktisi untuk meminimalisir perdarahan yang terjadi selama proses pengambilan frenulum dengan menggunakan pisau bedah. Maj Ked Gi; Desember 2011; 18(2): 187-190
\end{abstract}

Kata kunci: Insision below the Clamp, frenulum, perdarahan

\section{ABSTRACT}

Background. Attachment of high frenulum has negative impact on periodontal tissues as well as an aesthetic function. High attachment of frenulum that occurs in labialis superior, causing gingivitis and central diastema that are indications to do Frenectomy. Conventional techniques of Frenectomy performed with insisions above and below the clamp resulted in wide injury due to muscle contraction, which affects a lot of bleeding. Objective. To evaluate modification insision technique which hopefully can minimize the bleeding. Case and Treatment. This case report describes the handling of cases at high frenulum attachment that followed the central diastema. Patients with a diagnosis of high frenulum attachment and frenectomy indications be taken preoperatively, Surgery performed by using a scalpel, modification insision (Insision below the Clamp/IBC) is done by placing the clamp frenulum in a position adjacent and parallel to the lip, the insision carried out under the clamp, followed by suturing at the mucolabial fold. During the operation carried no visible wound widened, little of bleeding, patients and physicians are comfortable. Conclusion. IBC is a modification on frenektomy insision technique that can be done by general practitioners to minimize bleeding that occurs during frenectomy by using a scalpel. Maj Ked Gi; Desember 2011; 18(2): 187-190

Keywords: Insision below the Clamp, frenulum, bleeding

\section{PENDAHULUAN}

Perlekatan frenulum tinggi pada bibir atas terjadi pada permukaan labial antara insisivus sentralis maksila, adanya perlekatan ini berakibat timbulnya gingivitis dan diastema sentral ${ }^{1}$. Perlekatan frenulum tinggi pada area insisivus sentralis maksila ini lebih banyak insidensinya dibanding pada mandibula baik pada sisi labial maupun lingualnya ${ }^{2}$.

Frenulum yang terletak di sebelah anterior insisivus atas disebut frenulum labialis superior. Perlekatan frenulum tinggi terjadi karena pada saat pertumbuhan dan perkembangan gigi dan rahang tidak ikuti migrasi perlekatan frenulum kearah apikal ${ }^{3}$. Adanya abnormalitas ini menyebabkan pemisahan yang ekstrim dari gigi-gigi insisivus sentral, di samping itu membuat gingiva mudah terekoyak sehingga terjadi iritasi yang berkelanjutan yang menyebabkan kerusakan jaringan periodontal ${ }^{1}$. Perlekatan frenulum tinggi akan menghalangi proses pembersihan gigi, mengganggu pemakaian protesa gigi dan menghalangi pergerakan alat ortodonsi. Banyaknya dampak negatif yang muncul dengan adanya perlekatan frenulum tinggi menjadi dasar untuk dilakukan perawatan. Perawatan frenulum tinggi di atasi dengan pemotongan frenulum (frenotomi) atau dengan membuang seluruh bagian dari frenulum (frenektomi). ${ }^{4}$ Frenotomi dan frenektomi merupakan suatu prosedur bedah muko gingival yang paling sederhana dapat dilakukan dengan menggunakan pisau bedah atau electrosurgery ${ }^{1}$ dengan memotong dan atau mengangkat frenulum dari tempat insersi. ${ }^{5}$ Penghilangan frenulum yang menyeluruh, termasuk perlekatannya ke dasar tulang dapat dilakukan untuk mengoreksi diastema antara insisivus sentralis maksila ${ }^{6}$. 
Penggunaan scalpel pada frenektomi merupakan teknik yang umum dalam bedah di bidang kedokteran gigi, namun memiliki beberapa kelemahan diantaranya adalah banyaknya perdarahan ${ }^{5}$. Perdarahan pada frenektomi dapat diminimalisir dengan penggunaan electrosurgery, ${ }^{7,8}$ atau dapat dilakukan dengan memodifikasi teknik sayatan yang ada. Prosedur frenektomi pada umumnya dilakukan dengan insisi di atas dan di bawah clamp yang menyebabkan luka sobek yang melebar berbentuk belah ketupat karena adanya tarikan otot bibir, luka yang lebar pada area bibir menyebabkan banyak kapiler yang terbuka yang berakibat perdarahan ${ }^{9}$. Pada laporan kasus ini dipaparkan teknik insisi modifikasi Incision below the Clamp (IBC) yang ditujukan untuk mengurangi perdarahan saat frenektomi dengan menggunakan pisau.

\section{Frenektomi dengan teknik IBC}

Pemeriksaan secara rinci dilakukan meliputi anamnesa yang terdiri dari riwayat kesehatan sistemik, kesehatan dan perawatan gigi geligi yang telah dilakukan, jenis dan lama mengkonsumsi obat-obatan tertentu bila ada, pemeriksaan klinik ditujukan untuk mengevaluasi tingkat perlekatan dari frenulum dan perluasannya kearah palatinal, hingga dapat diyakini bahwa frenektomi sebagai salah satu tindakan yang harus dilakukan dalam perawatannya ${ }^{9,10}$. Pengambilan frenulum pada pasien dilakukan dengan menggunakan scalpel. ${ }^{10}$ Prosedur dasar pelaksanaan meliputi tindakan terapi fase awal untuk mempersiapkan kondisi kebersihan mulut yang baik meliputi tindakan scaling dan polishing. Pada tahapan operasi meliputi tindakan anesthesi, pemotongan frenulum dengan scalpel, suturing dan dressing dengan penggunaan pack periodontal' ${ }^{1}$.

\section{LAPORAN KASUS}

Pasien wanita berumur 23 tahun, dengan keluhan terdapat celah diantara gigi depan atas, hasil pemeriksaan subjektif pasien tidak menderita kelainan sistemik, dan tidak ada alergi. Riwayat Kesehatan gigi, keluhan tersebut dirasakan sejak usia anakanak, namun belum pernah dikonsultasikan dengan dokter gigi. Hasil pemeriksaan klinis menunjukkan adanya peradangan dan deposit di daerah interdental gigi insisivus sentral atas, pemeriksaan terhadap frenulum, dasar frenulum lebar dan tinggi meluas pada area interdental. Blanch test positif (Gb.1)

\section{Teknik Pelaksanaan Frenektomi}

Prinsip dasar yang dikerjakan pada teknik ini merupakan modifikasi step yang telah ada yaitu pada pemasangan clamp penjepit frenulum, lokasi insisi dan penjahitan. Anastesi infiltrasi dilakukan pada daerah vestibulum dilateral kanan dan kiri frenulum dilanjutkan pada daerah palatinal dekat foramen insisivus setelah didesinfeksi dengan menggunakan yod. Setelah teranestesi, klamp ditempat sejajar dan menempel pada bibir (Gb.2), insisi dilakukan di sebelah bawah dan sejajar klamp dari arah insisal menuju apikal/dasar vestibulum (Gb.3), suturing dilakukan segera setelah insisi pada daerah paling apikal dari insisi (Gb.4). dilanjutkan dengan pembersihan dan pengambilan jaringan ikat/muskulus penyusun frenulum yang meluas kearah palatinal (Gb.5 dan 6), dilakukan penutupan dengan periodontal pack (Gb.7), dan pemberian resep analgetik dan antibiotika.

\section{PEMBAHASAN}

Perlekatan frenulum tinggi terjadi bila puncak insersi dari pita bibir terletak pada margin atau pada papila interdental. Kondisi ini memudahkan mudah margin ginggiva tertarik sehingga plak mudah terjerat dalam sulkus yang berakibat timbulnya penyakit periodontal ${ }^{1}$. iritasi kronis oleh plak yang terjebak dalam gingiva berakibat timbulnya gingivitis dan terbentuk poket Dampak lain yang timbul adanya perlekatan frenulum tinggi adalah adanya diastema yang menyebabkan kesulitan dalam melakukan kontrol plak pada area interdental. Dari aspek estetik diastema gigi depan mengganggu penampilan, yang disebabkan karena jaringan fibrosa yang merupakan perluasan frenulum kearah palatinal, dalam hal perawatan ortodonsi pada kasus sentral diastema, jaringan fibrosa tersebut menyebabkan hambatan perawatan ortodonsi $.2,3,5$

Frenektomi menjadi suatu tindakan yang harus dilakukan pada perlekatan frenulum tinggi bertujuan untuk mencegah penyakit periodontal, perbaikan estetik karena adanya sentral diastema, pergerakan bibir yang terbatas,dan pengucapan yang tidak jelas ${ }^{1}$. Penggunaan scalpel dalam frenektomi merupakan cara yang umum dilakukan oleh dokter gigi, Beberapa kemungkinan yang sering timbul dengan penggunaan metode konvesional pada frenektomi adalah timbulnya luka yang lebar, diikuti keluarnya darah yang banyak selama proses operasi ${ }^{5,7}$. Modifikasi teknik insisi dan tahapannya pada studi kasus ini ditujukan untuk mengurangi lebar perlukaan dan perdarahan yang keluar. Modifikasi teknik frenektomi dengan pendekatan insisi di bawah clamp (Inscison below the clamps/IBC) pada laporan kasus ini adalah pertama, penempatan penempatan klamp sejajar dan menempel pada mukosa pipi, kedua, melakukan insisi di bawah klamp dan dilanjutkan dengan penjahitan segera setelah insisi pada area mucolabial fold. Hasil pengamatan menunjukkan bahwa insisi yang dilakukan di bawah clamp tidak menyebabkan luka yang melebar pada mukosa bibir, hal ini dikarenakan tarikan muskulus orbicularis oris kearah lateral tertahan oleh clamp, dan tindakan 
penjahitan yang dilakukan segera setelah insisi pada puncak sayatan akan menahan tarikan otot paska dilepasnya klamp. Penjahitan di samping ditujukan untuk menghubungkan jaringan yang terpotong juga untuk mengurangi perdarahan karena luka terbuka. Minimalisasi perdarahan yang terjadi, serupa dengan frenektomi yang dilakukan dengan menggunakan electrosurgery. 5,7,8,10,11 Tindakan operasi tanpa menimbulkan perdarahan yang banyak akan memberikan dampak psikis yang positif baik bagi pasien maupun dokter yang menanganinya ${ }^{5,7}$ Dokter gigi akan lebih tenang dan nyaman dalam melakukan pembersihan jaringan fibrosa dari ligamen penyusun frenulum.

Metode IBC berbeda dengan cara konvensional frenektomi, yang pada umumnya teknik frenektomi dilakukan dengan menjepit frenulum yang bisa memberikan akses untuk melakukan insisi baik di atas maupun di bawah clamp. Sayatan yang dilakukan di atas klamp pada teknik konvensional akan menyebabkan luka lebar, banyaknya kapiler pada mukosa bibir karena adanya luka terbuka akan menyebabkan banyak darah merembes keluar, begitu pula sayatan di bawah klamp dan pengangkatan jaringan yang terpotong akan menyebabkan daerah mucolabial fold tertarik kearah lateral yang memperburuk keadaan.

\section{KESIMPULAN}

Frenektomi pada perlekatan frenulum tinggi dengan teknik IBC memiliki keuntunga mengurangi perdarahan selama operasi, memberikan ketenangan bagi pasien dan operator dan dapat dilakukan dengan mudah oleh para dokter gigi.

\section{DAFTAR PUSTAKA}

1. Carranza Jr \& Newman GM: Clinical Periodontology, $9^{\text {th }}$. ed., W.B Saunders Company, Philadelphia, 2002: 112-113.

2. Grant D A, Stern I B, \& Everett F G: Orban's Periodontics, $4^{\text {th }}$ ed., Mosby Company, St. Louis, 1972: 530-55, 571-76.

3. Koora K, Muthu MS, \& Rathna PV: Spontaneous Closure of Midline Diastema Following Frenectomy. $J$ Indian Soc Pedod Prev Dent, 2007 Mar;25(1):23-6

4. Foster T D: Buku Ajar Ortodonsi, ed. III, EGC, Jakarta, 1999: 153-6.

5. Suryono: Gingivektomi dan Gingivoplasti pada Pembesaran Gingiva Pasca Perawatan Orthodonsia Menggunakan Electrosurgery, Majalah Kedokteran Gigi, Vol 14 (2) 2007: 149-154.

6. Newman M G, Takei H H, \& Carranza F A: Carranza' $s$ Clinical Periodontology, $9^{\text {th }}$ ed., W.B. Saunders Company, Philadelphia, 2002.

7. Suryono: Perbandingan Penggunaan Scalpel dan Electrosurgery pada Frenektomi Frenulum Labialis Superior, Majalah Kedokteran Gigi, 2009, Vol 16(1)

8. Shuman I E, Bipolar Versus Monopolar Electrosurgery: Clinical Application: 2001: 20 (12).http://www. dentistry today/monopolar versus bipolar electrosurgery.pdf 01/07/2007

9. Russell H: Atlas Berwarna Bedah Mulut Presprostetik, Buku Kedokteran EGC, 1989: 19-24.

10. Bagga S, Bhat KM, Bhat GS, Thomas BS: Esthetic Management of The Upper Labial Frenum: a Novel Frenectomy Technique. Quintessence Int. 2006;37(10):819-23.

11. Hausner K: Laser vs Electrosurgery. http:////laser vs electrosurgery.mht 01/07/2007 


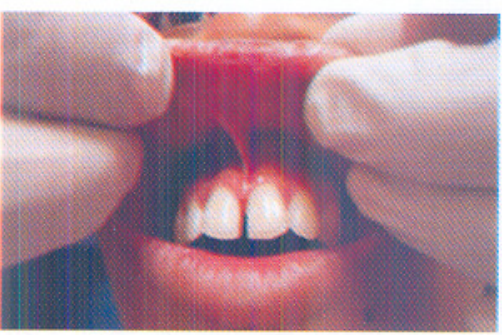

Gambar 1. Blanch test Positif dan peradangan di daerah interdental insisivus sentral

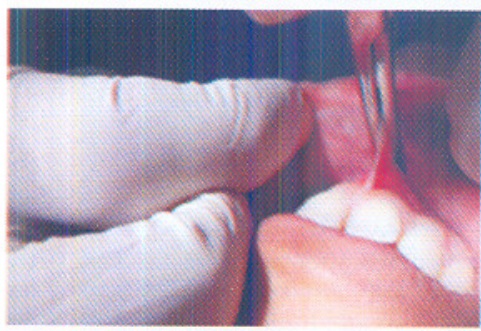

Gambar 2. Modifikasi penempatan klamp pada teknik IBC, klamp ditempatkan menempel dan sejajar bibir

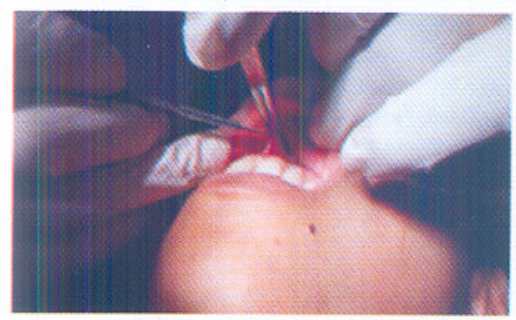

Gambar 3. Modifikasi insisi pada IBC, Insisi dilakukan di sebelah bawah dan menempel sejajar klamp

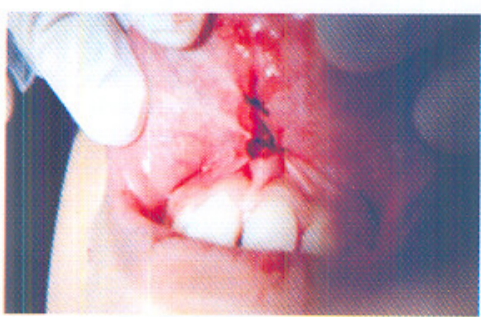

Gambar 4. Penjahitan dilakukan segera setelah insisi pada daerah mucolabial fold dan mukosa bibir

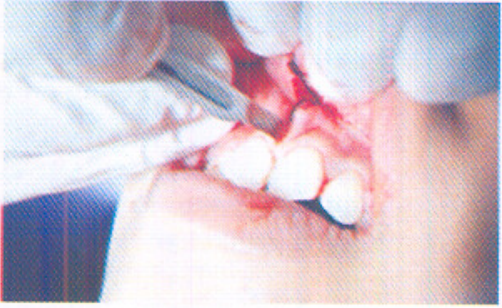

Gambar 5. Pengambilan jaringan ikat frenulum dilakukan setelah penjahitan

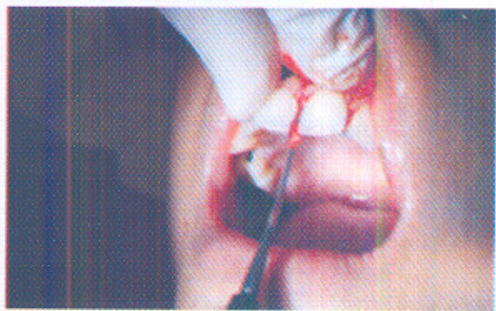

Gambar 6. Pengambilan dan pembersihan jaringan frenulum hingga pada daerah palatinal

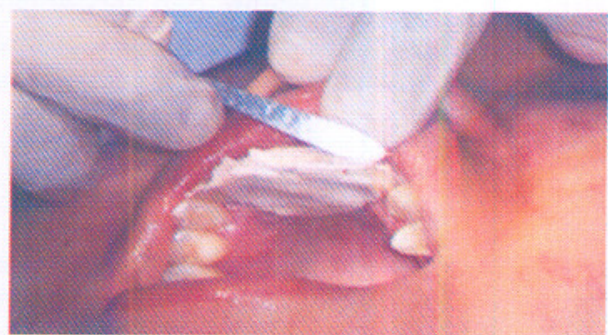

Gambar 7. Pemasangan periodontal pack 